\title{
Anthós
}

7-2012

\section{Entanglement: Health, Healing and Society in Africa}

Haley Noel

Portland State University

Follow this and additional works at: https://pdxscholar.library.pdx.edu/anthos

Part of the African History Commons, Health Policy Commons, and the History of Science, Technology, and Medicine Commons

Let us know how access to this document benefits you.

\section{Recommended Citation}

Noel, Haley (2012) "Entanglement: Health, Healing and Society in Africa," Anthós: Vol. 4: Iss. 1, Article 4. https://doi.org/10.15760/anthos.2012.62

This open access Article is distributed under the terms of the Creative Commons Attribution-NonCommercialShareAlike 4.0 International License (CC BY-NC-SA 4.0). All documents in PDXScholar should meet accessibility standards. If we can make this document more accessible to you, contact our team. 
Haley Noel

Entanglement: Health, Healing and Society in Africa

As a continent, Africa has been explored, exploited, and largely abandoned by the West. During the colonial era of the late $19^{\text {th }}$ and early $20^{\text {th }}$ centuries, foreign powers encountered diverse cultures, superstitions and disease before promptly labeling the entire continent a dangerous and primitive place. For early explorers and colonialists, disease and the threat of ill health is what defined Africa. They overlooked the pre-existing strategies and practices that Africans had adapted to guard against certain diseases, either ignoring them or labeling the misunderstood safety nets as primitive. Also overlooked was the importance of societal organization and communal cooperation among kin groups in the realms of health and economy. A false assumption of the continent as backwards and diseased spread among those living in the first world, and this legacy of thought is still in existence today. The history of health and healing in Africa is one of social ties and family economics, emphasizing the importance of kinship and community cooperation. While much of this essay focuses on the 19th and 20th centuries, it is of note that in certain areas, such as the Cape Town colony of South Africa, colonial interference extends back as early as the 16th century (Marks 208). During and after the colonial period, many of the important values and safety nets that had previously upheld the health and healing processes of Africans were renegotiated or abandoned, leaving behind the continued yet misperceived notion of Africa as a continent continuously riddled with disease. 
The importance of studying the interactions between health, healing and society rests in the centrality of medical discourse to the evolution of the modern state, and the increasing recognition of health and disease as social metaphors (Marks 206). In Africa, modern state building remains an elusive goal for many countries. However, it is important to acknowledge that when examining the communal structure of African societies, what is represented is most often an ideal that the communities themselves strive for but may never achieve in actuality. The extent of communalism is frequently overstated, and the notion of African cultures as static and immobile is false. “In order to make 'otherness' comprehensible, we have to present it as systematic,” states Susan Whyte (290). Any short discussion of African societies and cultures also tends to generalize, despite the incredible diversity of peoples, languages, and cultures represented within Africa.

Equally relevant is the fact that when studying health and healing and its changing place in African society, it is important to not assume that the pre-colonialist practices and safety nets of Africans were perfect or an appropriate model for the future. As Julie Livingston explains, “Relying on an 'African extended family' as the assumed site of long term care amid the social dislocations of global capitalism is a tenuous move," (13). Neil Kodesh also states how "the disorder and demographic collapse that accompanied the establishment of colonial rule in many parts of Africa rendered inoperable previous processes of social mobilization,” (199). Yet what is evident in the way pre-colonialist African societies were structured is the importance of community and family to economic, physical, and social survival. 
When the Transatlantic slave trade reached into Central Africa in the $17^{\text {th }}$ century, a new disease appeared that brought Africans together in one of the greatest healing cults evidenced by historians (Prins 176). It was a social disease of greed known as lemba, and it became synonymous with trade and capitalism. This extraordinary fact depicts how in the beginning of European incursions into the continent, the Africans foresaw a fundamental threat to their society and banded together in an attempt to cure what they saw as a societal sickness. This is highly indicative of African thought, that when faced with large issues the solution lay in community. The problem was met head-on by communal cooperation, and while lemba cults clearly did not protect against further erosion of African societies, it is clear evidence supporting African ideas of societal illness and attempted cure through communal cooperation. A similar example is the almost cult-like belief in tokwakwa tales, in which white people act as vampires and eat black bodies (Hunt 1999: 182). The threat of white doctors in these tales was used as a form of societal control, keeping communities united against the lure of the whites, who were widespread representations of modernization and colonialism.

Numerous safety nets existed before colonialists attempted to "fix" what they perceived as the backward ways of Africans. These safety nets, encompassing the realms of physical health and societal well-being, show that the two are intrinsically linked. One such example can be found in Tanzania, where a study found that abandoned practices of widow inheritance, in which a man could inherit the widows and children of deceased male relatives, directly led to widespread malnutrition (Feierman 1985: 83). In this case, the women and children that would otherwise have been inherited by a male family member and cared for were suddenly left to fend 
for themselves, experiencing malnutrition in the name of modernization and the abandonment of what colonialists viewed as a backwards practice. In the early 1900’s in the Belgian Congo, colonial officials wasted time and money creating failed strategies for vector control of tsetse fly belts, ignoring the advice of local populations who had already established when and where to not travel in order to avoid disease (Malowany 332). Even ideologies regarding kinship were seen by missionaries as pagan, who emphasized the "need to promote Christian notions of the family, rather than reinforcing 'traditional’ kinship ideologies,” (Vaughan 68). Birth spacing was an African practice that enabled women to nurse their babies for longer periods of time, ensuring infant health (Hunt 1988: 407). Yet colonialists effectively stopped this practice in a concerted effort to "breed” African labor, leading not only to overpopulation fears but increasing rates of child malnutrition.

These examples indicate not only the arrogant mindset of colonialists in ignoring successful African strategies on control of disease and maintenance of health, but depict how social values and cooperation were crucial to the overall health of African communities: "a person's health or illness depended on her access to the spiritual, intellectual, and material resources of a group of relatives, living and dead,” (Feierman 2000: 331).

One reason contributing to the incursions of colonialists was the colonialist's confidence in the benefits of biomedicine. In this blind belief of colonialists in the superiority of biomedicine over African safety nets, “the inference that other aspects of European colonialism were as well intentioned, as worth having (and therefore as legitimate) as its medicine... was used explicitly... to promote their empire,” (Prins 162). 
A primary social importance of health and healing rests in the ability of those involved in the healing and curing processes to influence others: "the power to name an illness, to identify its causes, is also the power to say which elements in the experience of life lead to suffering," (Feierman 1985: 75). This ideology gives much power to popular healers, who colonialists then labeled witch doctors or medicine men. This offensive terminology ignores the social roles that popular healers occupied, not only as physical healers but as social harmonizers who worked towards maintaining positive relationships in communities. The abilities of healers typically resulted in greater authority, as the knowledge of healing was often ascribed to close communion with ancestors (Landau 264). The link between physical and social health was strong, as many African societies believe that negative relationships with family members, neighbors, and/or ancestors could negatively impact physical health. Societal harmony was reinforced by the threat of illness, and popular healers were often the ones behind the scenes maintaining both realms of health. This notion of control was familiar to colonialists, and "as many writers have pointed out, the cultural construction of illness through biomedical discourse is a powerful tool of social control,” (Vaughan 73). Popular healers played a large role in bringing communities together and keeping the peace, encouraging communal cooperation. When colonialists labeled these popular healers as “witch doctors,” they delegitimized a vital centripetal force in communities.

Popular healers were associated by colonialists with the superstitions and other various African religious beliefs that missionaries sought to replace with Christianity. Missionaries used medicine to aid spiritual conversion, and "the asserted superior power of European medicine over African treatment of disease was held to demonstrate the validity of Western rational 
explanation over African superstition,” (Ranger 258). This linkage of health to religion was a rare common ground for Africans and missionaries, even though specific perceptions remained diverse. For many Africans, there was typically no delineation between society, health, and religion; rather all three made up the composition of daily life. For missionaries, the links between Christian communities and living a moral life in society are known to most Western readers. It can be argued that missionaries took advantage of this perceived similarity of community to create converts. However, "mission medical provision with its scientific rationality was not experienced by Africans as a continuing part of Christ’s ministry,” (Ranger 259). Early biomedical incursions into African ideology were therefore rejected on the grounds of singularity, depicting widespread African beliefs of universal interconnectedness. Missionaries were often viewed as extensions of the government, and colonialists in general, so this ignorance of the importance of community in African societies continues the trend of failing to recognize the centrality of communalism to the belief system of Africans.

Medical missionaries and colonialists attempted to individualize the societies they encountered in Africa. While a clear ignorance of the importance of kinship and communalism is evident, it is likely this attempted individualization of African communities is due to colonialist ideas on control. In contrast to a united community, individuals are easier to control- something that was desired by colonialists who were eager to utilize Africans as labor. This ideology of the individual directly combatted prevalent African notions of interconnectedness, which emphasized "implicit connections between the body and the society," (Landau 269). In examining the role of the individual in African health and healing, Landau further goes on to 
mention the European avoidance of dealing with societal causes of disease, and how colonial medicine overlooked wider community dynamics in favor of focusing on individual bodies (270). The colonial focus on the individual also had roots in biomedicine, which was further problematic as "Africans did not share with medical missionaries clear cut distinctions between cause, diagnosis, disease, and cure,” (White 1385). The attempt of colonialists to divide communities that valued communal cooperation is therefore a perpetuation the practice of ignoring pre-existing safety nets. In this case, the African focus on the overall well-being of the community played a central role in uniting societies against the incursions of the colonialists. This was clearly a hindrance to colonialist ideas of individualization.

In addition to influencing the arena of health and its dominance in dictating social relationships, this lack of individualism also directly influenced local African economies and labor supply. Value was placed not on accumulating personal wealth and success, but of contributing to and increasing the success of your kin and community: "the ideology and practices of clanship... furnished the conceptual bridge connecting transformations in agriculture and public healing,” (Kodesh 197). While this quotation is in reference to the expansion of banana farming in Uganda, the primary role of clanship and community in resource production and control is of central importance in the broader picture of African communalism. In the face of the often harsh realities of African life, conditions such as famine, epidemics, and warfare required communities to unite and collaborate in efforts to ensure collective well-being (Kodesh 204). Young men were often viewed as community labor resources, able to assist not only in agriculture and cattle production but in ensuring safety in times of conflict. Communities also 
relied on new and diverse knowledge bases to ensure their success (Kodesh 208), which is evidence against the colonial perception of African societies as immobile and static. The African emphasis of economic cooperation and resource sharing not only contributed to stronger communities and therefore stronger communal well-being, but acted as a safety net against crises.

Despite extensive cooperation among clans and communities, misfortune naturally still occurred. When evaluating misfortune in an African context, ills that affect society are viewed as more harmful than ills that merely affect an individual. This harkens back to links between economics and health, when a bad harvest meant the ill health of an entire community. Susan Whyte takes it further, stating that "interpretations of misfortune are related to particular social contexts and specific positions within society,” (290). This explains categorizations of misfortune along lines of social relationships and gendered expectations. The Tswana social condition of mopakwane assumes the form of various ailments such as the common cold or anemia, and afflicts the child of a parent who commits a sexual taboo. It is a highly categorized misfortune that reinforces societal values such as confinement abstinence and fidelity (Livingston 173). The threat of physical debility is a form of social control, as "diseases and their subsequent nursing burdens reminded women of the perils of violating their twin moral ties to their menfolk and their children,” (Livingston 175). While mopakwane is often viewed as a female misfortune, the broad social implications of illness and misfortune extend to numerous cultures and societies outside of Botswana. While certain former sexual taboos are now viewed with more leniency, 'by the end of the colonial period, girls' and young women’s bodies and reputations remained 
crucial sites for constructing and contesting political and moral order," (Thomas 177). This indicates the centrality of communal health to the overall success of a community, and is further evidence of how social constructions and values acted as vital safety nets for maintaining successful communities.

Some of the alarm surrounding the current HIV/AIDS epidemic in Africa contains traces of these former societal values. Lynn Thomas explains that many East and Central Africans regard the spread of HIV/AIDS as a social and moral problem, blaming loose values and promiscuity for the spread of the deadly disease (182). Contemporary solutions to problems revolving around health and healing in Africa also contain traces of the communal structure of past societies. The HIV/AIDS epidemic has acted as a catalyst in the formation of non-traditional kin groups, in which members are not related and not from the same villages. An example of this is the milieu, an informal network of gay men (Nguyen 162). International organizations have attempted to create social networking groups among those affected by HIV/AIDS, yet these attempts often fail due to differing notions of community among Africans. NGO ideology entails the process of money creating communities, when for many Africans it goes the opposite direction: communal groups are a source of resources. This continued failure of Western organizations to understand African ideology and needs is reminiscent of colonialist disregard for pre-existing safety nets, both depicting how in relations with Africa, non-Africans tend to view their own practices as superior to those of the 'diseased continent,' perpetuating the notion of disease as "both a biological fact and a social metaphor," (Swanson 408). Therefore community 
health, healing, and success is all dependent on positive social relationships and communal cooperation.

Going forward, a reversion back to the communal ways of health and healing before colonialism is clearly not an option. Globalization and capitalism have effectively eroded much of the former value placed on communal wealth and well-being, yet social relationships remain an important facet of everyday African life. As technology is improved and mortality declines, the increasing number of people living with chronic diseases and other forms of debility face healing in an entirely new way. "Biomedicine may well have much to learn from the experience of those non-Western healers who see the need to treat social disease as well as individual illhealth, and understand that resolving social tensions is part of the healing process,” (Marks 219). While a physical cure may continue to be elusive, the relationships surrounding a debilitated person become all the more important. Pre-colonialist African societies incorporated these ideas of communal well-being and cooperation into daily life, erasing the traces of separation between individual and community. They extended ideas of communal cooperation to economics and safety, issues now relegated to individual responsibility. However, "even the lives of the ‘modern’ could never be fully detached from older hierarchies rooted in local notions,” (Thomas 186). While communal cooperation in the realm of wealth and resources is not a viable contemporary practice to fall back on, ideologies regarding strong personal relationships that provide social support are still important in many facets of modern African activity. 
Works Cited

Feierman, Steven. “Explaining Uncertainty in the Medical World of Ghaambo.” Bulletin of the History of Medicine 74 (2000): 317-344.

Feierman, Steven. "Struggles for Control: The Social Roots of Health and Healing in Modern Africa.” African Studies Review 28:2/3 (1985), 73-147.

Hunt, Nancy Rose. “Nurses and Bicycles.” A Colonial Lexicon of Birth, Medicalization and Mobility in the Congo. Duke University Press Books, 1999: Chapter Four.

Hunt, Nancy Rose. “Le Bebe en Brusse”: European Women, African Birth Spacing and Colonial Intervention in Breast Feeding in the Belgian Congo.” International Journal of African Historical Studies 21:3 (1988), 401-432.

Kodesh, Neil. “Networks of Knowledge: Clanship and Collective Well-Being in Buganda.” The Journal of African History 49:2 (2008): 197-216.

Landau, Paul. “Explaining Surgical Evangelism in Colonial Southern Africa: Teeth, Pain and Faith.” The Journal of African History 37:2 (1996), 261-281.

Livingston, Julie. Debility and the Moral Imagination in Botswana. University of Indiana Press, 2005.

Marks, Shula. "What is Colonial about Colonial Medicine? And What has Happened to Imperialism and Health?” Social History of Medicine 10:2 (1997), 205-219.

Malowany, Maureen. “Unfinished Agendas: Writing the History of Medicine of Sub-Saharan Africa.” African Affairs 99 (2000): 325-349. 
Nguyen, Vinh-Kim. The Republic of Therapy: Triage and Sovereignty in West Africa's Time of AIDS. Duke University Press, 2010.

Prins, Gwyn. "But What Was the Disease? The Present State of Health and Healing in African Studies.” Past and Present 124 (1989), 159-179.

Ranger, Terence. “Godly Medicine: The Ambiguities of Medical Missions in Southeastern Tanzania.” in Steven Feierman and John Janzen, eds., The Social Basis of Health and Healing in Africa (1992), 256-282.

Swanson, Maynard W. "The Sanitation Syndrome: Bubonic Plague and Urban Native Policy in the Cape Colony, 1900-1909.” The Journal of African History, 18:3 (1977): 387-410.

Thomas, Lynn. Politics of the Womb: Women, Reproduction, and the State in Kenya. University of California Press, 2003.

Vaughan, Megan. "The Great Dispensary in the Sky: Mission Medicine.” Curing their Ills: Colonial Power and African Illness. Stanford University Press, 1991: 55-76.

White, Luise. "They Could Make their Victims Dull: Genders and Genres, Fantasies and Cures in Colonial Southern Uganda.” American Historical Review 100:5 (1995), 1379-1402.

Whyte, Susan. “Anthropological Approaches to African Misfortune, from Religion to Medicine.” Anita Jacobsen-Widding and David Westerlund, eds., Culture, Experience, and Pluralism: Essays on African Ideas of Illness and Healing (1989). 